\title{
UPAYA MENGEMBANGKAN KREATIVITAS ANAK MELALUI KEGIATAN BERMAIN KONSTRUKTIF DENGAN MENGGUNAKAN MEDIA BALOK DI TK ALIFEA SAMARINDA
}

\author{
Andi Aslindah \\ Universitas Widya Gama Mahakam Samarinda \\ aslindah.andirezky@yahoo.com
}

\begin{abstract}
This study aims to determine the development of children's creativity through constructive play activities using media blocks. Constructive play is a form of game by using physical objects to build or create things. This game occurs when children engage in a creation or construction of a product or a problem solving of their own creation. This research is a Classroom Action Research (PTK) or Classroom Action Research. This study was conducted in two cycles. Subjects in this study were group A semester II of Kindergarten Alifea academic year 2016/2017, as many as 13 children (5 women and 8 men) with the aspect that is assessed that is participation, attention, independence, creativity and ability to tell. Data creativity of children in constructive play with media beam collected by using the method of observation with the instrument in the form of observation format sheet. Research data were obtained and analyzed qualitatively. Based on the results of data analysis obtained is on the first cycle of $46.1 \%$, Cycle II obtained data of $81.5 \%$ So there is an increase in creativity development from cycle I to cycle II of $35.4 \%$
\end{abstract}

Keywords: Constructive Playing, Media Beams, Child Creativity 
Jurnal Warna : Jurnal Pendidikan Dan Pembelajaran Anak Usia dini. Maret 2018. Vol 03. No. 01

\section{PENDAHULUAN}

Sebagai negara berkembang, Indonesia sangat membutuhkan tenaga kreatif yang mampu memberi sumbangan bermakna kepada ilmu pengetahuan, teknologi dan kesenian serta kepada kesejahteraan bangsa pada umumnya. Sehubungan dengan ini pendidikan hendaknya juga tertuju pada pengembangan kreativitas bukan hanya berorientasi pada perkembangan intelegensi, khususnya bagi anak usia dini.

Menurut Utami Munandar (1992 : 45), kreativitas perlu dikembangkan sejak usia dini karena: Pertama, dengan berkreasi anak dapat mewujudkan dirinya dan ini merupakan kebutuhan pokok manusia; Kedua, kreativitas atau cara berfikir kreatif, dalam arti kemampuan untuk melihat berbagai kemungkinan dalam pemecahan masalah, hal ini masih kurang diperhatikan dalam pendidikan formal. Ketiga, bersibuk diri secara kreatif akan memberikan kepuasan pada diri anak. Hal ini sering terlihat pada anakanak yang bermain konstruktif sehingga terkadang mereka lupa terhadap kegiatan yang lain; Keempat karena kreativitas mampu meningkatkan kualitas manusia dan taraf hidupnya.

Secara etimologi, kreativitas berasal dari kata benda (noun) "creativity" yang berarti daya cipta. Menurut Komite Penasehat Nasional bidang Pendidikan Kreatif dan Pendidikan Budaya, kreativitas adalah suatu bentuk aktivitas imajinatif yang mampu menghasilkan sesuatu yang bersifat original, murni, asli dan bermakna (Anna Craft, 2004 : 1)

Sedangkan pengertian yang lain, istilah kreativitas diartikan suatu kemampuan seseorang untuk menghasilkan komposisi, produk atau gagasan apa saja yang pada dasarnya baru dan sebelumnya tidak dikenal pembuatnya. Kreativitas bisa juga mencakup pembentukan pola baru dan gabungan informasi yang diperoleh dari pengalaman sebelumnya dan pencangkokan hubungan lama ke situasi baru sehingga menghasilkan tujuan. Kreativitas dapat berupa produk seni, kesusasteraan, produk ilmiah atau metodologi (Tim Pustaka Familia, 2006: 252).

William dalam Munandar menyatakan bahwa ciri-ciri kreativitas dapat ditinjau dari dua aspek, yaitu :

a. Aspek Kognitif. Ciri-ciri kreativitas yang berhubungan dengan kemampuan berpikir kreatif/divergen yaitu : 1) keterampilan berpikir lancar (fluency), 2) keterampilan berpikir luwes/fleksibel (flexibility), 3) Keterampilan berpikir orisinal (originality), 4) keterampilan 
Jurnal Warna : Jurnal Pendidikan Dan Pembelajaran Anak Usia dini. Maret 2018. Vol 03. No. 01

memperinci (elaboration), dan 5) keterampilan menilai (evaluation). Makin kreatif seseorang, maka ciri-ciri tersebut makin dimiliki.

b. Aspek Afektif. Ciri-ciri kraetivitas yang berkaitan dengan sikap dan perasaan seseorang yaitu : a) rasa ingin tahu, b) Bersifat imajinatif/fantasi, c) merasa tertantang oleh kemajemukan, d) sifat berani mengambil resiko, e) sifat menghargai, f) percaya diri, g) keterbukaan terhadap pengalaman baru, dan $\mathrm{h}$ ) menonjol dalam satu bidang seni.

Program kreativitas bermain susun balok secara spontan merupakan suatu proses belajar yang tepat untuk anak. Balok-balok ini akan menjadi media seni bagi anak. Mereka adalah ilmuwanilmuwan kecil yang ingin sekali menjelajah dunia, para seniman kecil menggunakan desain/bentuk polanya sendiri sesuai dengan bentuk, ukuran, warna dan pengulangannya. Hal yang menarik dari bermain balok ini adalah banyak pengalaman menarik dapat dituangkan anak secara kreatif dalam membangun balok tersebut. Daya penalaran anak akan bekerja aktif, konsentrasi pada waktu bermain balok akan semakin meningkat. Bermain balok juga dapat membangkitkan pengertian mereka sampai tak terhinggga. Konsep pengetahuan matematika ada di tangan dan ujung jari mereka, nama, bentuk, balok kubus, selinder, jembatan, balok panjang, balok pendek, balok segitiga, pengertian sama, beda, seimbang, posisi sama tinggi dan sebagainya.

Ada beberapa manfaat permainan balok yang dapat dilihat pada anak usia prasekolah, antara lain : a) Manfaat Fisik : Mainan balok memperkuat gengaman jari dan tangan anak, meningkatkan koordinasi mata dan tangan. Mainan balok juga mendidik anak mempelajari perbedaan bentuk geometri; b)Manfaat Sosial :Mainan balok mendorong anak untuk berteman dan bekerja sama. Balok bermanfaat bagi anak karena balok mendorong interaksi dan imajinasi. Imajinasi anak dapat segera diwujudkan dengan mainan balok. Kreatifitas yang dikombinasikan dengan aksi sangat penting dalam kehidupan sosial; c) Manfaat Intelektual :Anak dapat mengembangkan kemampuan kata-kata saat mereka mencoba menggambarkan ukuran, bentuk dan posisi. Anak mengembangkan kemampuan matematik melalui pengelompokan, penambahan, pengurangan. Dua buah segitiga sama sisi jika digabung akan menjadi persegi empat. Hal tersebut bisa juga akan dimengerti melalui bermain balok standar. Dengan 
bermain balok, anak akan mengalami bahwa balok jika tidak seimbang akan jatuh, anak belajar tentang keseimbangan dan gravitasi. Belajar geometri dari mainan balok akan meningkatkan stimulasi intelektual; d) Manfaat Kreatif : Mainan balok merupakan pemicu stimulasi kreatifitas, karena anak akan membuat desain mereka sendiri dengan balok. Plato Seorang Philosofi Yunani (428-348 SM) menulis bahwa arsitek masa depan adalah anak yang mainannya membuat bangunan.

Dari uraian di atas maka dapat dikemukakan bahwa pengembangan kreativitas pada anak, khususnya usia prasekolah sangat penting. Namun usaha kearah itu harus lewat kegiatan yang digemari dan menjadi kehidupan anakanak pada saat itu yaitu bermain.Dengan menerapkan prinsip bermain sambil belajar maka anak akan menjadi lebih kreatif dan pada saat yang sama akan menjadi lebih gembira. Dengan bermain anak akan merasa senang secara spontanitas sehingga mampu memberikan rasa aman secara psikologis pada anak. Begitu pula dengan suasana bermain aktif, anak akan memperoleh kesempatan yang luas untuk melakukan eksplorasi guna memenuhi rasa ingin tahunya serta anak bebas mengekspresikan ide-idenya. Untuk mencapai tujuan tersebut dibutuhkan intensitas bermain yang baik dan berkualitas dalam merangsang imajinasi untuk mengembangkan kreativitas anak. Salah satu bentuk permainan yang dapat meningkatkan kreativitas adalah permainan konstruktif.Jenis permainan konstruktif yang popular adalah membuat sesuatu misalnya dari lempung, pasir, balok, lilin, cat, kertas dan sebagainya. Dengan bermain konstruktif anak tidak akan bosan-bosannya menggabungkan dan menyusun bentuk-bentuk kombinasi yang baru dengan alat permainannya. Permainan konstruktif tidak akan membuat anak merasa bosan karena dalam permainan ini yang dipentingkan adalah hasilnya dan kesenangan.Dalam hal ini permainan balok dianggap paling menggairahkan dan mengasyikkan karena dapat digunakan berulang kali dan berbagai cara oleh anak.

Berdasarkan uraian diatas maka penulis tertarik untuk mengupayakan pengembangan kreativitas anak usia prasekolah melalui kegiatan bermain konstruktif dengan menggunakan media balok karena dalam permainan ini anak akan terus menggunakan daya imajinasinya untuk menghidupkan permainan ini dengan membuat hal-hal yang baru. 


\section{METODE PENELITIAN}

Metode penelitian pada dasarnya yang dipergunakan untuk memecahkan masalahpenelitian. Penelitian yang penulis gunakan adalah penelitian tindakan kelas.Penelitian tindakan kelas ini dilakukan untuk memperbaiki dan meningkatkankualitas pembelajaran yang dilakukan oleh guru dan bagi penulis sendiri untuk memperolehhasil belajar yang baik serta memuaskan. Subjek dalam penelitian ini adalah anak TK Alifia Kelompok A sebanyak 13 anak yang terdiri dari 8 laki-laki dan 5 perempuan.

Penelitian dilaksanakan pada semester genap tahun ajaran 2016/2017.Penelitian ini akan dilakukan secara bersiklus, yang dimulaidari kondisi awalkemudiansiklus

pertama danlanjutsiklus keduadengan prosedur dari penelitian yang akanpeneliti lakukanterdiri empat tahap penting Penelitian tindakan kelasmenurut Arikunto(2006:16 ) adalah: a) perencanaan, b) pelaksanaan, c) pengamatan, d) refleksi.Jika dalamsiklus I belum berhasil dan meningkat, peneliti akan melakukan perbaikan kegiatanpembelajaran berdasarkan hal-hal yang belum dicapai pada siklus I. Pada siklus II ini akandilakukan sama dengan siklus I yaitu perencanaan, pelaksanaan, pengamatan, danrefleksi.Dalam penelitian ini data dikumpulkanmelalui teknik observasidan dokumentasi.Data dianalisis dalam persentase dengan mengunakan rumus oleh Hariyadi (2009:24)sebagai berikut :

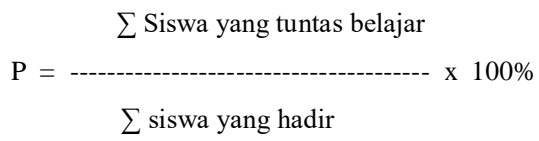

\section{HASIL DAN PEMBAHASAN}

\section{HASIL PENELITIAN}

Berdasarkan hasil penelitian yang diperoleh dari pelaksanaan tindakan pada siklus I dan siklus II pada pengembangan kreativitas anak dalam bermain konstruktif dengan media balok terjadi peningkatan mulai dari kondisi awal, siklus I dan siklus II. Untuk lebihjelasnya hasilnya dapat dilihat pada tabel dan grafikdibawah ini :

\section{Tabel 1.Hasil Observasi}

\begin{tabular}{|c|c|c|c|c|c|}
\hline No & $\begin{array}{c}\text { Aspek yang } \\
\text { diamati }\end{array}$ & $\begin{array}{c}\text { Kondisi } \\
\text { Awal } \\
\end{array}$ & $\begin{array}{c}\text { Siklus } \\
\text { I }\end{array}$ & $\begin{array}{c}\text { Siklus } \\
\text { II }\end{array}$ & Keterangan \\
\hline 1 & $\begin{array}{c}\text { Anak Mampu } \\
\text { Partisipasi }\end{array}$ & 4 & 8 & 10 & \multirow{2}{*}{ Berkembang } \\
\hline \multicolumn{2}{|c|}{ Ketuntasan $(\%)$} & $30,1 \%$ & $61,5 \%$ & $\begin{array}{c}76,9 \\
\%\end{array}$ & \\
\hline 2 & $\begin{array}{c}\text { Anak Mampu } \\
\text { Perhatian }\end{array}$ & 2 & 6 & 10 & \multirow{2}{*}{ Berkembang } \\
\hline \multicolumn{2}{|c|}{ Ketuntasan (\%) } & $15,3 \%$ & $46,2 \%$ & $76,9 \%$ & \\
\hline 3 & $\begin{array}{c}\text { Anak Mampu } \\
\text { Mandiri }\end{array}$ & 1 & 4 & 11 & \multirow{2}{*}{ Berkembang } \\
\hline \multicolumn{2}{|c|}{ Ketuntasan (\%) } & $7,7 \%$ & $30,1 \%$ & $84,6 \%$ & \\
\hline 4 & $\begin{array}{c}\text { Anak Mampu } \\
\text { kreatif }\end{array}$ & 5 & 7 & 11 & \multirow{2}{*}{ Berkembang } \\
\hline \multicolumn{2}{|c|}{ Ketuntasan (\%) } & $38,5 \%$ & $53,8 \%$ & $84,6 \%$ & \\
\hline 5 & $\begin{array}{c}\text { Anak Mampu } \\
\text { Berkomunikasi }\end{array}$ & 5 & 8 & 10 & \multirow{2}{*}{ Berkembang } \\
\hline \multicolumn{2}{|c|}{ Ketuntasan (\%) } & $38,5 \%$ & $61,5 \%$ & $76,9 \%$ & \\
\hline
\end{tabular}


Keterangan : pengembangan kreativitas anak TK Alifia Kelompok B melalui permainan konstruktif dengan menggunakan media balok pada kondisi awal, siklus I, dan siklus II dengan kategori Nilai Berkembang Sangat Baik (BSB) dan Berkembang Sesuai Harapan (BSH)

Berdasarkan tabel hasil observasi mulai dari kondsi awal, Siklus Idan Siklus II, dapat dilihat perkembangan dalam beberapa aspek dalam upaya mengembangkan kreativitas anak melalui permainan konstruktif dengan menggunakan media balok yaitu :Aspek lanak mampu berpertisipasi dalam bermain balok, pada kondisi awal adalah $30,1 \%$, pada siklus I menjadi $61,5 \%$ dan siklus II meningkat menjadi $76,9 \%$. Persentase peningkatan dari kondisiawal pada siklus I yaitu $31,4 \%$ dan dari siklus I kepada siklus II yaitu naik 15,4\%.Aspek 2anak mampu perhatian dalam melakukan permainan, pada kondisi awal adalah 15,3\% pada siklus I menjadi $61,5 \%$ dan siklus II meningkat menjadi 76,9\%. Peningkatan darikondisi awal pada siklus I yaitu 30,9\% dan dari siklus I kepada siklus II yaitu 30,7\%.Aspek 3 anak mampu mandiri melakukan permainan balok, pada kondisi awaladalah 7,7\%, pada siklus I menjadi $30,1 \%$ dan siklus II meningkat menjadi $84,6 \%$. Persentasepenigkatan dari kondisi awal sampai siklus I yaitu $22,4 \%$, dan dari siklus I sampai siklusIInaik menjadi 54,5\%.Aspek 4 anak mampu kreatif menyusun balok, pada kondisiawal adalah 38,5\%, pada siklus I menjadi 53,8\% dan siklus II meningkat menjadi 84,6\%.Persentase peningkatan dari kondisi awal kepada siklus I yaitu 15,3\% dan dari siklus Ikepada siklus II yaitu naik 30,8\%.Aspek 5 anak mampu mengkomunikasikan hasil karyanya, pada kondisi awal adalah $38,5 \%$, pada siklus I menjadi $61,5 \%$ dan siklus II meningkatmenjadi $\quad 76,9 \%$. Persentase peningkatan dari kondisi awal kepada siklus I yaitu $23 \%$ dandari siklus I kepada siklus II yaitu naik 9,4\%.

\section{PEMBAHASAN}

Pada kondisi awal peneliti mengamati kreativitas anak di kelompok A di Taman Kanak-kanak Alifia masih rendah. Oleh karena itu peneliti tertarik melakukan penelitian tindakan kelas dalam mengupayakan pengembangan kreativitas anak melalui kegiatan bermain konstruktif dengan menggunakan media balok.

Mengembangkan kreativitas anak sejak dini sangat penting dilakukan. Dan pada dasarnya setiap anak memiliki potensi untuk kreatif, walaupun tingkat kreativitasnya berbeda-beda. Kreativitas 
seperti halnya setiap potensi lain, perlu diberi kesempatan dan rangsangan oleh lingkungan untuk berkembang. Perkembangan kreativitas anak bukan hanya dipengaruhi oleh lingkungan psikis saja tetapi lingkungan fisik juga memiliki andil yang cukup besar.

Dalam penelitian ini, peneliti mengharapkan dengan diterapkannya permainan konstruktif dengan menggunakan media balok dapat mengupayakan peningkatan kreativitas anak didik di Alifia Kelompok A. Adapun indikator penilaian peneliti dalam melihat kreativitas siswa yaitu antara lain sebagai berikut : (1) Anak mampu berpatisipasi aktif dalam menggunakan media belajar yang disiapkan dan aktif bertanya. (2) Anak mampu berkonsentrasi dalam jangka waktu yang lama dalam melakukan kegiatan bermain balok, (3) Anak mampu mandiri dan percaya diri menyelesaikan susunan baloknya tanpa bantuan orang lain (4) Anak mampu merealisasikan fantasi imajinasinya dalam bentuk nyata yaitu berupa susunan balok yang bagus (menyerupai sesuatu) (5) Anak mampu menceritakan bentuk bangunan yang disusunnya (hasil ciptaannya)

Indikator kreativitas anak yang ditetapkan oleh peneliti di atas sebagai pedoman observasi berdasarkan dari ciri- ciri anak yang kreatif, diantaranya sebagai berikut : (1) Rasa ingin tahunya yang besar dan senang berimajinasi, (2)Suka mencoba hal-hal yang sulit dan kegagalan tidak membuatnya putus asa, (3) Peka terhadap apa yang dilihat, didengar, diraba dan dialaminya, (4) Senang mencoba sesuatu yang baru, (6) Mampu mengerjakan pekerjaannya sendiri (mandiri) dan berani mengambil resiko (7) Terbuka terhadap masukan orang lain (fleksibel), (8)Memiliki rentang perhatian yang lebih lama. Bahkan karena terlalu sibuk dengan pikirannya sehingga dia jadi sering tidak menyimak pembicaraan orang-orang disekitarnya, (9) Bisa menemukan macammacam kegunaan suatu benda hanya dengan imajinasinya, (10) Sering memberi jawaban yang unik terhadap suatu pertanyaan.

Dari uraian di atas maka peneliti menggabungkan dan merinci lalu menetapkan lima (5) aspek penilaian kreativitas anak dalam bermain konstruktif dengan media balok yaitu : Partisipasi, Perhatian, Kemandirian, Kreativitas, Bercerita.

Pada penelitian tindakan siklus I kegiatan permainan konstruktif masih menggunakan balok-balok dengan ukuran kecil dengan berbagai bentuk tetapi tidak berwarna. Kegiatan bermain balok pada 
siklus I berjalan baik hanya hasil yang diharapkan anak bisa aktif dan kreatif dalam kegiatan bermain konstruktif dengan media balok ternyata belum memuaskan peneliti. Berdasarkan hasil pengamatan yang dilakukan oleh peneliti, kondisi kreativitas anak dalam menyusun balok pada kelompok A, guru mengalami kendala/hambatan, diantaranya pada saat media belajar sudah disiapkan dan diberikan kebebasan kepada siswa untuk menyusun baloknya sendiri ternyata hanya beberapa siswa saja yang aktif menyusun balok-balok yang sudah disiapkan. Hal ini disebabkan karena media balok yang digunakan kurang menarik minat anak, kemungkinan karena baloknya yang tidak berwarna. Selain itu faktor kendalanya adalah karena keterampilan guru dalam memberikan motivasi dan keterampilan guru berkreasi dalam memberikan contoh dalam kegiatan kepada anak masih kurang. Sedangkan target yang ditetapkan oleh peneliti adalah masing-masing aspek memiliki skor minimal 75\%. Sehingga peneliti dan kolaborator merencanakan untuk melakukan perbaikan tindakan yang akan dilakukan pada siklus selanjutnya.

Pada kegiatan bermain konstruktif dengan menggunkan media balok pada siklus II ini berlangsung dengan baik, anak kelihatan senang dan antusias, sehingga suasana kelas jadi ramai dan gembira. Hal ini disebabkan karena media balok yang digunakan adalah balok-balok yang mempunyai warna-warni yang cerah dan menarik. Selain itu guru terlihat lebih aktif dalam membimbing siswa serta membangun keberanian siswa untuk aktif menggunakan media belajar yang sudah disiapkan. Sehingga target yang ditetapkan oleh peneliti sudah mencapai lebih dari $75 \%$. Kelima aspek penilaian sebagai indikator perkembangan kreativitas sudah mencapai lebih dari $75 \%$.

Dalam kegiatan bermain balok ini, terlihat anak begitu senang, bebas dan gembira selama kegiatan berlangsung. Karena dengan bermain balok anak akan merasa senang secara spontanitas sehingga mampu memberikan rasa aman secara psikologis pada anak. Begitupula dengan suasana bermain aktif, anak akan memperoleh kesempatan yang luas untuk melakukan eeksplorasi guna memenuhi rasa ingin tahunya serta anak akan bebas mengekspresikan ide-idenya.

\section{KESIMPULAN DAN SARAN}

\section{A. KESIMPULAN}

Yang dapat peneliti simpulkan dari penelitian ini adalah : (1) Pengembangan kreativitas anak di Tk Favorit Samarinda Utara dengan metode permainan 
konstruktif dengan menggunakan media balok ternyata sangat baik dilihat dari aspek partisipasi, perhatian, kemandirian, kreativitas serta kemampuan anak menceritakan hasil ciptaannya. Hal ini terlihat dari sikap anak yang merasa senang dan gembira selama pelaksanaan kegiatan. (2) Melalui kegiatan bermain konstruktif dengan media balok disimpulkan dapat meningkatkan kreativitas anak. Hal ini terlihat dari peningkatan hasil penilaian yaitu pada kondisi awal hanya $26,02 \%$, pada siklus I diperoleh hasil 50,62\%, pada siklus II diperoleh 79,98\%.

\section{B. SARAN}

Diharapkan guru selalu mempersiapkan dengan baik metode dan media yang cocok untuk kegiatan yang akan dilaksanakan, selain itu berusaha berlatih untuk menjadi guru yang lebih kreatif sehingga dapat menjadi model bagi anak didik dan dapat membina anak didik dalam mengembangkan kreativitasnya maupun dalam kemampuan lainnya. Selain kegiatan bermain balok, tenaga pendidik sebaiknya lebih banyak memberikan kegiatan yang bisa merangsang kreativitas anak seperti membentuk dan menggambar bebas.

\section{DAFTAR PUSTAKA}

-------------.(2006). Panduan Bimbingan di TK. Jakarta: Departemen Pendidikan Nasional.

Departemen Pendidikan Nasional. (2005). Kamus Besar Bahasa Indonesia Edisi Ketiga. Jakarta: Balai Pustaka.

Devi Ari Mariani. (2008). Bermaindankreativitasanakusiadini. Jakarta: Balai Pustaka

Hartati, Sofia. 2005. Perkembangan Belajar Pada Anak Usia Dini. Jakarta : Departemen Pendidikan Nasional

Hurlock, E. B.(1978).Perkembangan Anak Jilid 1. (Alih Bahasa:Meitasari Tjanadrasa) Jakarta : Penerbit Erlangga.

Mayke S. Tedjasaputra. (2001). Bermain, Mainan dan Permainan untuk Pendidikan Anak Usia Dini. Jakarta: Grasindo.

Miles, M. B \& Huberman, A. M. (1992). Analisis Data Kualitatif.(Alih Bahasa: Tjetjep Rohendi Rohidi) Jakarta:Universitas Indonesia-Press.

Mulyadi. S, 2004, Bermain dan Kreativitas. Jakarta : Papas Sinar Sinanti.

Mulyasa. (2009). Penelitian Tindakan Kelas. Bandung: PT.Remaja Rosdyakarya 